\title{
STRUKTUR REPRESENTASI EKSTERNAL SISWA PADA TRANSISI PENGETAHUAN BAGUN RUANG KE BANGUN DATAR
}

\author{
Syarifudin $^{1}$, Ummu Fikriyah ${ }^{2}$ \\ ${ }^{1}$ Program Studi Pendidikan matematika STKIP Taman Siswa Bima \\ ${ }^{2}$ Guru SMPN 4 Nguling Pasuruan. \\ e-mail: syarifudin.abubakar@yahoo.co.id ${ }^{1}$,ummufikriyahsyarifudin@yahoo.co.id ${ }^{2}$
}

\begin{abstract}
Abstrak
Tujuan penelitian ini adalah untuk mendeskripsikan struktur representasi eksternal siswa tentang transisi pengetahuan mereka dari bangun ruang ke bangun datar. Penelitian ini dilakukan kepada 8 siswa SMP yang sudah menempuh materi bangun ruang. Data diperoleh dari hasil pekerjaan siswa tentang membuktikan soal luas permukaan tabung dan hasil wawancara mendalam. Data-data tersebut direduksi, diverifikasi dan dianalisa. Hasil penelaitian menunjukkan bahwa representasi eksternal siswa tentang transisi pengetahuan mereka memiliki tiga karakteristik. Pertama siswa membuktikan soal tersebut dengan jawaban persegi panjang dan dua lingkaran, kedua dengan jawaban jajar genjang dan dua lingkaran, dan ketiga ada jawaban dua persegi panjang didapat dari satu persegi panjang utuh dan 4 setengah lingkaran bagian dari tutup dan alas tabung.
\end{abstract}

Kata Kunci : Struktur Representasi, Transisi, dan Bangun Ruang

\section{PENDAHULUAN}

Pengembangan kemampuan matematis siswa merupakan salah satu sasaran utama dalam pembelajaran matematika. Tujuan dari pengembangan pengetahuan ini adalah agar siswa lebih memahami konsep yang dipelajarinya dan dapat digunakan dalam memecahkan masalah. Supaya bisa berkembang seperti yang diharapkan, siswa dituntut untuk memiliki kemampuan representasi matematisnya. Hal ini seperti yang diungkapkan oleh NCTM (2000) bahwa representasi adalah salah satu dari lima kemampuan yang hendaknya siswa ketahui dan dapat dilakukannya, yaitu: pemecahan masalah, penalaran, komunikasi, koneksi, dan representasi. Fennel (2011) mendefinisikan representasi adalah proses, komponen penting dari pengajaran dan pembelajaran, cara untuk menunjukkan model matematika, dan cara bagi siswa untuk menunjukkan pemikiran mereka tentang matematika. Jadi kemampuan siswa dalam merepresentasikan ide atau gagasan adalah suatu keharusan yang dimiliki oleh setiap siswa.

Merepresentasikan ide atau gagasan tersebut bisa dilakukan dengan berbagai cara. Cara yang biasa dilakukan misalnya dengan diagram (gambar) atau sajian benda konkrit, 
tabel chart, pernyataan matematika, teks tertulis, ataupun kombinasi dari semuanya. Dalam berbagai cara tersebut, menurut Hiebert dan Carpenter (1992) representasi dapat dikelompokkan menjadi dua yaitu representasi ekternal dan internal. Representasi ekternal yang berkaitan tentang berpikir ide matematika dan wujudnya antara lain: verbal, gambar dan benda konkrit. Dan berpikir tentang ide matematika yang memungkinkan pikiran seseorang bekerja atas dasar ide tersebut merupakan representasi internal. Lebih lanjut Goldin (2002) menyatakan bahwa representasi eksternal adalah hasil perwujudan dalam menggambarkan apa-apa yang dikerjakan siswa secara internal atau representasi internal. Hasil perwujudan ini dapat diungkapkan baik secara lisan, tulisan dalam bentuk kata-kata, simbol, ekspresi atau notasi matematik, gambar, grafik, diagram, tabel, atau objek fisik berupa alat peraga. Jadi representasi adalah bentuk interpretasi pemikiran siswa terhadap sesuatu masalah baik berupa kata-kata atau verbal maupun tulisan, gambar, tabel, grafik, atau simbol matematika lainnya.

Dua representasi ini telah membantu siswa dalam menyampaikan ide atau gagasannya. Goldin (2001) menyatakan bahwa interaksi antara representasi internal dan eksternal merupakan dasar untuk mengajar dan belajar yang efektif. Wetzels, Kester, \& Merrienboer (2010) menyatakan bahwa representasi eksternal terdiri dari dua bentuk yaitu representasi descriptive dan depictive. Representasi descriptive (verbal) terdiri atas simbol yang mempunyai struktur sembarang dan dihubungkan dengan isi yang dinyatakan secara sederhana dengan makna dari suatu konvensi, yakni teks, sedangkan representasi depictive (gambar) termasuk tanda-tanda ikonik yang dihubungkan dengan isi yang dinyatakan melalui fitur struktural yang umum secara konkret atau pada tingkatan lebih abstrak, yaitu, display visual. Ketika siswa dihadapkan pada suatu situasi masalah matematika dalam pembelajaran di kelas, mereka akan berusaha memahami masalah tersebut dan menyelesaikannya dengan cara-cara yang mereka ketahui. Salah satu cara yang dapat dilakukan siswa adalah dengan membuat model atau representasi dari masalah tersebut. Model atau representasi yang di buat bisa bermacam-macam tergantung pada kemampuan masing-masing individu dalam menginterpretasikan masalah yang ada.

Misalnya pada materi bangun ruang, materi ini membutuhkan kemampuan siswa dalam merepresentasikan konsep geometris yang berbentuk abstrak menjadi bentuk tulisan atau sebaliknya. Hal ini terjadi karena dalam materi ini berisikan simbol-simbol, rumusrumus atau gambar yang menunjukkan adanya transisi dari suatu titik, garis, atau bidang tertentu. Pada materi ini, peneliti akan menyusun struktur representasi ekstrernal siswa dari hasil pengerjakaan soal-soal. Sturktur representasi ekternal yang dimaksudkan adalah suatu yang disusun dengan pola tertentu dan saling berhubungan satu sama lain yang berkaitan tentang berpikir ide matematika dan wujudnya berupa verbal dan gambar yang berkaitan dengan persegi panjang, jajar genjang, dan lingkaran serta keterangan-keterangannya. Oleh karena itu, peneliti inggin mengali banagaimana struktur representasi eksternal siswa SMP pada pengetahuan mereka tentang transisi bangun datar ke bangun ruang? Tujuan dari penelitian ini adalah untuk mendeskripsikan struktur representasi ekternal siswa tentang trasisi bangun datar ke bangun ruang. 


\section{METODE}

Penelitian ini merupakan penelitian kualitatif dengan jenis penelitian deskriptif eksplorasi. Peneliti mengambil subjek dari sekelompok siswa yang telah mempelajari materi bangun ruang sisi lengkung. Tujuan yang diharapkan dalam penelitian ini adalah untuk mendapatkan struktur representasi eksternal siswa tentang pengetahuan mereka dari transisi bangun datar ke bangun ruang yang sudah tersimpan dalam memorinya. Pengambilan data dialakukan dengan cara memberikan soal tentang bangun ruang sisi lengkung. Siswa diminta untuk mengerjakan soal-soal tersebut dengan pengetahuan yang sudah dimulikinya. Dari jawaban siswa diperoleh data tertulis yang bersifat deskripstif tentang kemampuan siswa dalam mengerjakan soal. Data tersebut dianalis dengan pendektakan analisis konten (Cohen, 2007). Jawaban siswa dianalisis dan direduksi sesuai dengan data yang diharapkan. Berikut ini adalah instrumen tes yang digunakan dalam penelitian ini.

Gambarlah suatu tabung dengan jari-jari dan tinggi sembarang. Dari hasil gambar tersebut, buktikan bahwa luas permukaan tabung adalah $2 \pi r(r+t)$ dan hitunglah luas permukaannya?

Dari soal tersebut, ada dua tipe soal yaitu soal pembuktian dan soal perhitungan. Dua soal ini memiliki tujuan adalah siswa diharapkan mampu membuktikan dengan cara menggambar. Dan soal ke dua diharapkan siswa mengerjakan perhitungan, karena soal tersebut harus dipotong, maka harapanya adalah siswa akan mempertimbangkan panjangnya jari-jari atau tinggi tabung tersebut berkurang.

\section{HASIL}

Hasil penelitian ini akan dipaparkan dari 3 subyek yang disimbolkan S1, S2, dan S3. Tiga subyek ini dipilih karena memiliki jawaban berbeda dari teman-teman yang lainnya dan peneliti menilai jawaban mereka akan tergambar tentang adanya transisi pengetahuan siswa dari bangun datar ke bangun ruang. Hasil pengerjaan S1 dapat dilihat berikut ini.

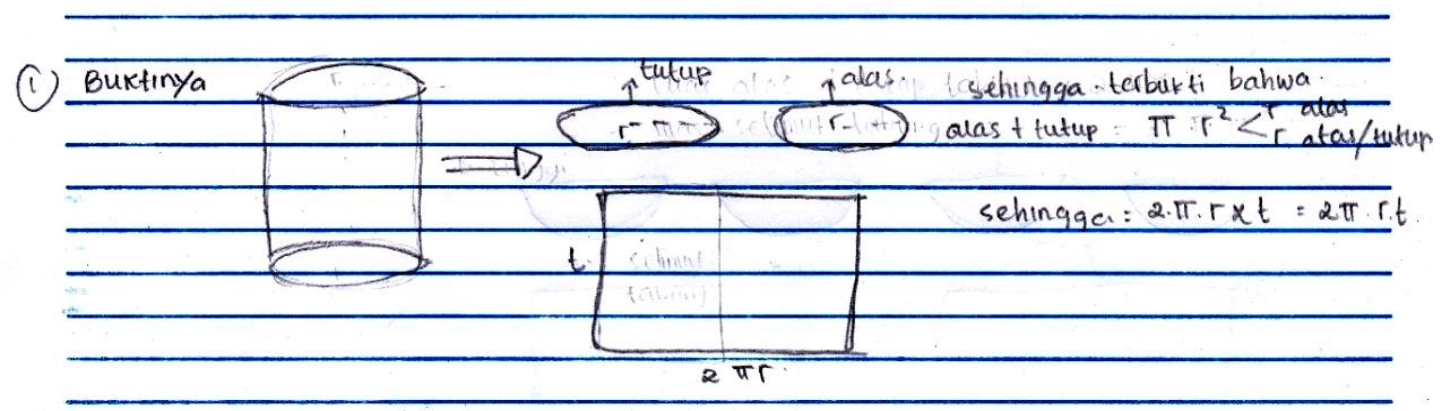

Gambar 1. Jawaban soal pembuktian oleh S1. 


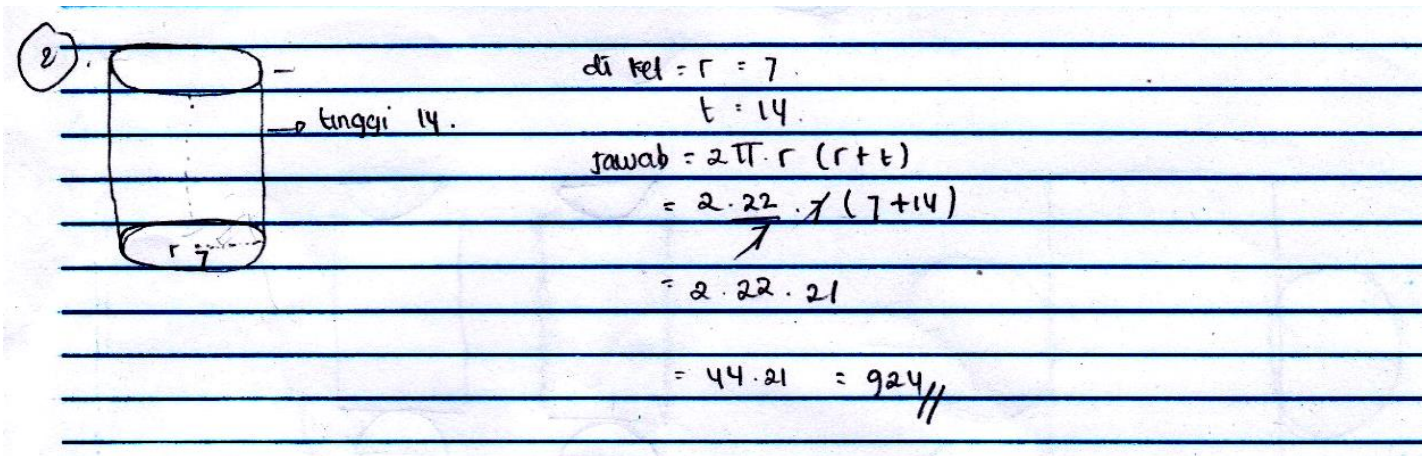

Gambar 2. Jawaban soal hitungan oleh S1.

Dari hasil pekerjaan S1 tersebut bahwa untuk membuktikan luas permukaan tabung, dia mengambar jaring-jaring tabungnya. Dari gambar jaring-jaring tabung, siswa memisahmisahkan menjadi beberapa bangun datar. Bangun datar tersebut berupa satu persegi panjang dan dua lingkaran. Supaya peneliti mendapatkan alasan kenapa S1 menjawab sepeti itu, maka peneliti melakukan wawancara. Berikut ini cuplikan wawancara peneliti tentang proses pengerjaan siswa tersebut.

$\mathrm{P} \quad$ : kenapa harus digambar seperti ini?

S1 : tujuannya supaya saya bisa membuktikan soal ini pak guru.

$\mathrm{P} \quad$ : masah sih... harus seperti itu

S1 : iya pak... saya pernah belajar tentang ini, pada tabung ini saya potong menjadi persegi panjang, tutup dan alas bentuknya lingkaran.

$\mathrm{P}$ : apa yang kamu lakukan dari gambar ini (saya tunjuk gambarnya dia)

S1 : inikan persegi panjang, kalau rumus persegi panjang itu adalah panjang dikali lebar,

$\mathrm{P} \quad$ : berarti $P \times L$ dong...

S1 : bukan... setahu saya rumusnya itu $2 \pi r t$

$\mathrm{P} \quad$ : tahu dari mana rumus seperti itu?

S1 : kan... sebelum saya gambar menjadi bentuknya seperti persegi panjang, ini seperti keliling tabung yang berbentuk lingkaran (dia tunjuk gambar tabung), makanya saya sebut $2 \pi r t$

$\mathrm{P} \quad$ : masak.. rumus keliling lingkaran seperti itu?

S1 : mmm.... oh iya $t$ nya itu sebagai tinggi tabung pak

$\mathrm{P} \quad$ : loh... katanya rumus persegi panjang tadi $P \times L$, berarti bukan $t$ donk?

S1 : pak guru... sama aja tinggi dengan lebar itu

$\mathrm{P}$ : oh begitu... trus bagaimana dengan gambar kedua lingkaran ini?

$\mathrm{S} 1$ : rumus luas atap tabung yang berbentuk lingkaran ini adalah $\pi r^{2}$

$\mathrm{P}$ : kamu ketahui dari mana?

S1 : dulu saya pernah kegaiatan sama ibu guru, kami dapatkan seperti itu.

$\mathrm{P}$ : oke lah kalau begitu... terus kamu apakan dari rumus-rumus tersebut.

S1 : ini rumus luas permukaan persegi panjang dan dua luas tutp dan alas... sehingga kalau ditambahkan menjadi (dia tunjuk tulisan)

$\mathrm{P} \quad$ : Selain berbentuk persegi panjang, apakah ada bentuk lain?

S1 : iya ada pak guru

Selain peneliti tanya proses S1 mengerjakan bukti tersebut, peneliti menanyakan tentang gambar-gambar yang dia buat. Berikut ini cuplikan wawancaranya.

$\mathrm{P} \quad$ : tabung itu apakah tergolong bangun ruang atau bangun datar?

S1 : mmm... bangun ruang pak guru 
$\mathrm{P} \quad$ : apa alasannya?

S1 : karena ada ruang yang kosong di dalam ini (dia tunjuk tengah-tengah gambar tabung)

$\mathrm{P} \quad$ : trus dari kegita gambar yang kamu buat ini, tergolong bangun ruang atau datar

S1 : bangun datar pak guru, karena gambar ini (sambil menunjuk gambar) memiliki panjang dan lebar

$\mathrm{P}$ : kok gambar melingkarnya tidak seperti lingkaran?

S1 : maaf pak... tapi ini lingkaran dari atas dan alasnya tabung

$\mathrm{P} \quad$ : kamu pernah belajar tentang jaring-jaring bangun ruang

S1 : iya pernah pak guru..

$\mathrm{P}$ : trus hubunganya yang kamu gambar ini dengn pelajaran tersebut apa

S1 : nah.. yang saya gambar ini adalah jaring-jaring tabung

$P$ : apa hanya bisa seperti ini aja gambarnya

S1 : Tidak pak guru..

$\mathrm{P} \quad$ : coba kamu gambarkan model-model yang lainnya

Selanjutnya peneliti wawancara subyek S2. Berikut ini hasil wawancara dan jawaban pekerjaan yang berbeda dari subyek S2.

Jawaban Pembuktian oleh S2.

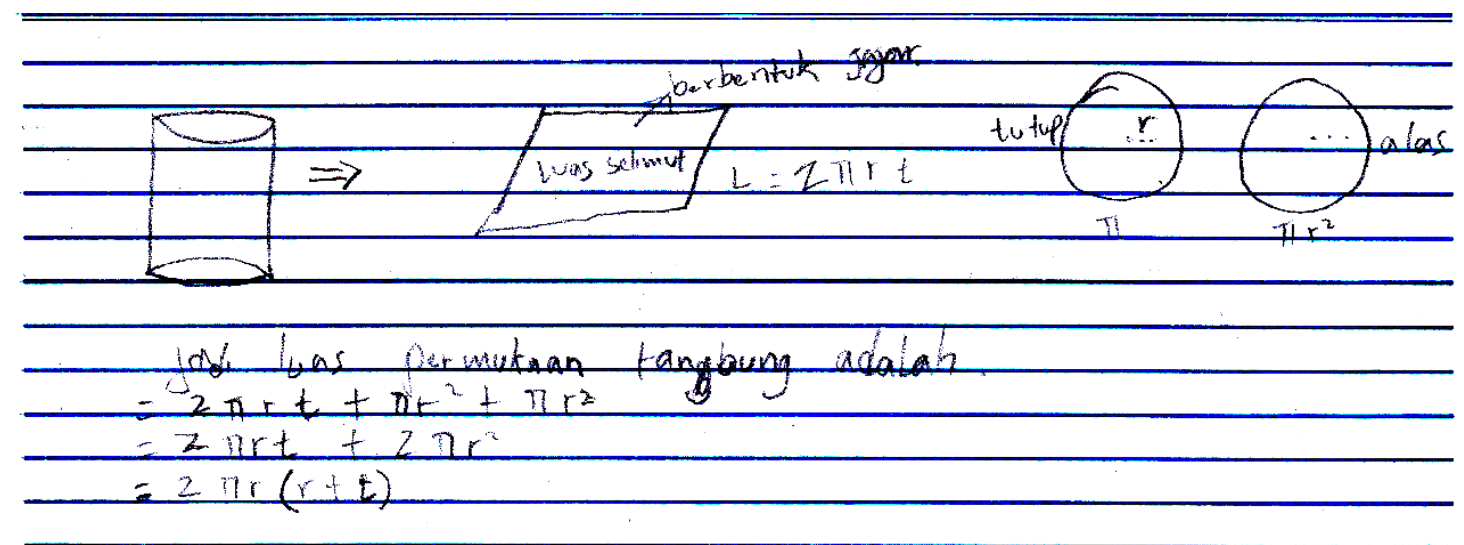

Gambar 3. Jawaban soal pembuktian oleh S2.

Dari jawaban tersebut, saya mewawancari secara mendalam tentang jawaban S2.

$\mathrm{P}$ : kenapa hasil jawaban kamu ini beda dengan jawaban dari banyak teman

S2 : kan ... yang penting sama tujuannya pak guru

$\mathrm{P}$ : oh begitu... apa alasanya gambar berbentuk jajar genjang

S2 : ini pengalaman dari hasil kegiatan sama ibu guru dulu, makanya sama aja jawabannya pak guru

P : pintar...

Lebih lanjut berikut ini uraian jawaban S3 dan cuplikan hasil wawancara peneliti dengan S3. 


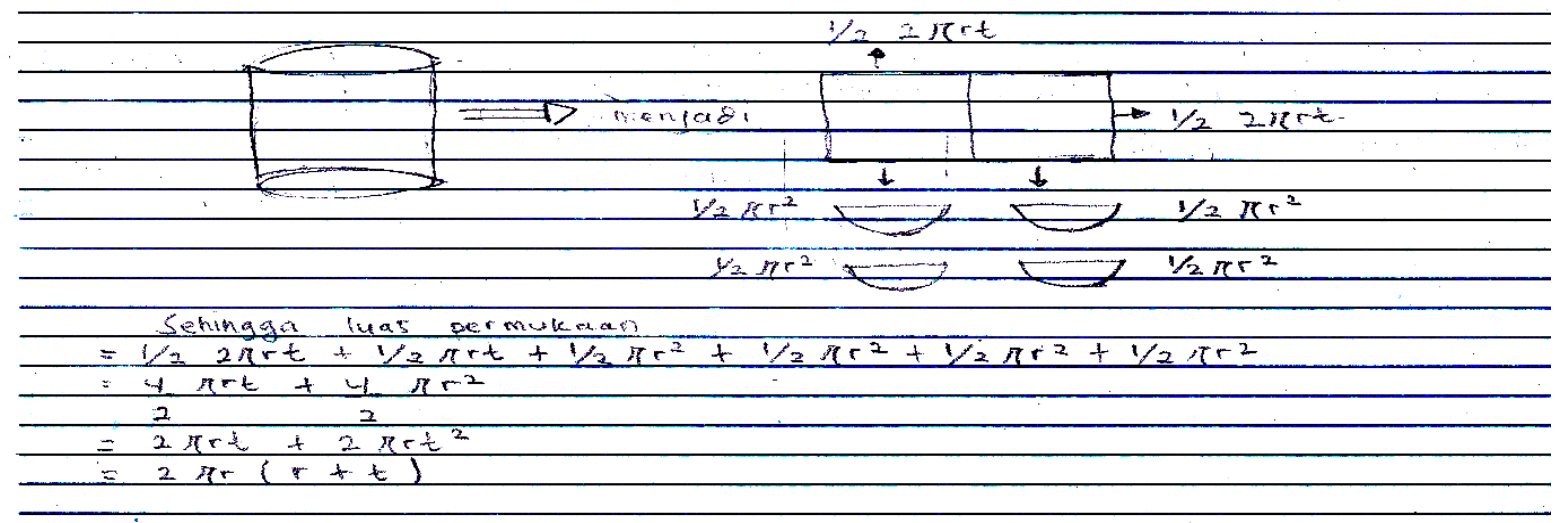

\section{Gambar 4. Jawaban soal pembuktian oleh S3.}

Dari jawaban tersebut, peneliti mewawancara secara mendalam ke S3.

$\mathrm{P}$ : kenapa kamu punya pikiran membagi empat dua lingkaran menjadi setengah lingkaran.

S3: dulu saya waktu lakukan kegiatan dengan ibu guru... saya kesulitan memotong alat peraga tabung. Akhirnya saya gunting membagi dua aja tabung tersebut.

$\mathrm{P}$ : trus langkah kamu selanjutnya apa?

S3 : bingung ... dan dibantu oleh ibu guru. Akhiynya saya punya gambar seperti ini (dia menunjuk gambarnya)

$\mathrm{P}$ : pintar..

Setelah saya mewawancar tentang proses pengerjaan soal pertama, saya lanjutkan dengan wawancara soal perhitungan. Pada soal kedua ini ada harapan saya tentang pemikiran mereka setelah dipotong tabungnya akan berubah panjang dan tingginya dari permukaanya itu. Hal tersebut belum saya temukan. Berikut ini cuplikan wawancaranya dari salah satu subyek penelitian. Hal ini karena jawaban mereka sama semua. Berikut ini cuplikan wawancaranya.

$\mathrm{P}$ : dari panjang jari-jari dan tinggi tabung ini, setelah dipotong apakah tidak berkurang panjangnya?

$\mathrm{S} 1: \mathrm{mmm}$... oh iya ya... (semau siswa tidak memirkan hal tersebut)

$\mathrm{P}$ : jika berkurang, bagaimana?

S1 : Berarti luar permukaan tabung yang kami hitung ini salah pak guru ya?

$\mathrm{P}$ : iya donk.... tap tidak apa-apalah...

\section{PEMBAHASAN}

Hasil penelitian ini, dapat dijelaskan bahwa siswa membuktikan luas permukaan tabung dengan cara mengambar beberapa bagian bangun ruang menjadi bangun datar. Cara seperti ini merupakan cara merepresentasikan suatu ide atau gagasan dalam bentuk gambar. Wetzels, Kester, \& Merrienboer (2010) menyatakan representasi ekternal salah satunya dengan gambar (depictive). Cara siswa membuktikan dengan gambar dari bangun ruang menjadi bangun datar merupakan suatu cara untuk mempermudahkan mereka. Ini berarti bahwa pengolahan representasi bergambar mungkin memerlukan upaya mental kurang dari pada pengolahan representasi verbal (Cox, 1999; Mayer, 2001). 
Hasil-hasil pekerjaan tersebut, bisa kita ketahui bahwa cara-cara siswa mengerjakan soal-soal dengan menggunkan pengetahuan sebelumnya. Proses membangun representasi eksternal dan berinteraksi dapat menumbuhkan pemahaman peserta didik, terutama jika representasi memiliki tingkat kesulitan yang tinggi (Wetzels, Kester, \& Merrienboer, 2010). Dari pengetahuan atau pemahaman mereka, maka mereka dapat menggambarkan jaringjaring tabung. Mereka dapat menggambarkan dengan cara yang bermacama-macam. Hal ini sesuai dengan pandangan NCTM (2000) bahwa siswa menggunakan representasi untuk memodelkan dan menginterpretasikan fenomena fisik, sosial, dan fenomena matematika.

Siswa menjawab pembuktian tentang luas permukaan tabung dengan cara mengambarkan dua lingkaran dan satu persegi panjang. Dari gambar ini mereka menentukan rumus luas lingkaran yang ada dibagian atas tabung adalah $\pi r^{2}$ dan luas lingkaran yang ada

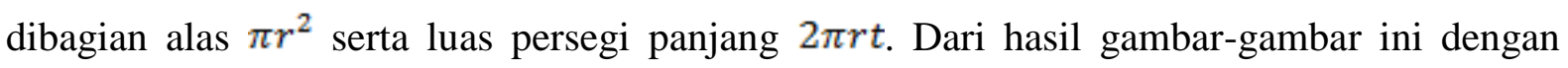
sudah ditentukan rumus luas masing-masinya, selajutnya siswa menjumlahkan sehingga menghasilkan luas tabung adalah $\pi r^{2}+\pi r^{2}+2 \pi r t=2 \pi r^{2}+2 \pi r t=2 \pi r(r+t)$. Dalam wawancara, peneliti menanyakan kenapa luas persegi panjang adalah $2 \pi r t$, siswa menjawab bahwa persegi panjang tersebur berawal dari keliling tabung yang berbentuk lingkaran. Jadi $2 \pi r$ adalah keliling lingkaran dan jika gambar dalam bentuk bagun datar, maka akan terbentuk panjang persegi panjang dan $t$ sebagai tingi tabung tersebut. Berikut ini jawaban siswanya.

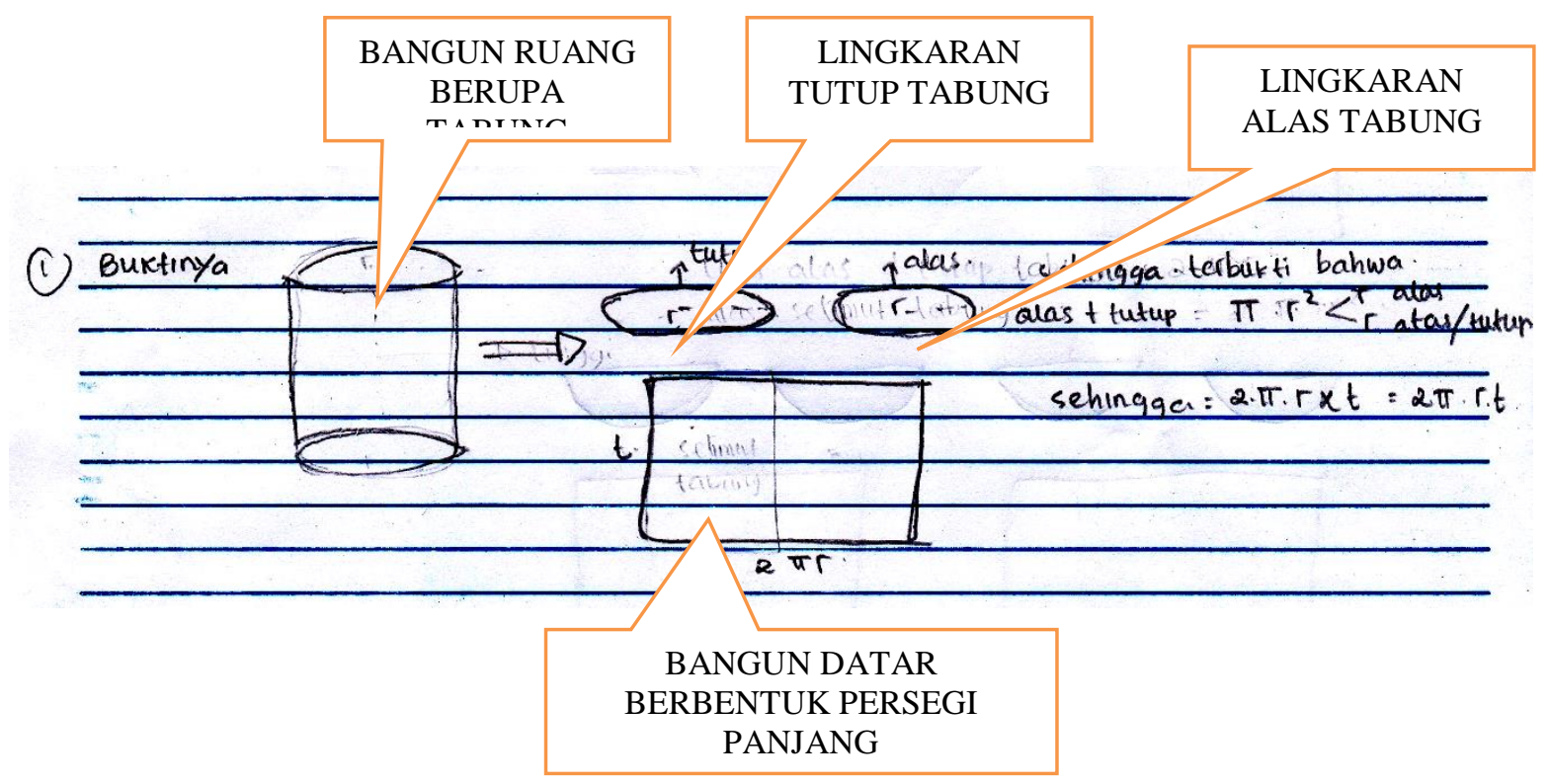

\section{Gambar 5. Jawaban soal pembuktian oleh S1.}

Bagi siswa menjawab soal dengan membuktikan luas permukaan tabung dengan cara mengambar bagung datar dua lingkaran dan satu jajar genjang. Siswa ini mengambar dua lingkaran dan jajar genjang memiliki alas. Alasan dia mengambar jajar genjang adalah ketika siswa sudah pernah melakukan pembuktian luas permukaan tabung dengan menggunakan gunting yang besar, sehingga dia sulit menggunting secara lurus. Akhirnya dia menggunting miring. Pada awalanya dia tidak percaya diri melanjutkan pengerjaan tersebut. Setelah dibinbing oleh guru, akhirnya dia bisa juga. Untuk luas lingkaran sebagai alas dan tutup 
tabung adalah berturut-turut $\pi r^{2}$ dan $\pi r^{2}$. Sedangkan luas jajar genjang adalah $2 \pi r t$. Jadi luas permukaan tabung adalah $\pi r^{2}+\pi r^{2}+2 \pi r t=2 \pi r^{2}+2 \pi r t=2 \pi r(r+t)$. Berikut ini hasil jawaban siswa tersebut.



\section{Gambar 6. Jawaban soal pembuktian oleh S2.}

Ada jawaban siswa yang lebih unik lagi. Dia mengembangkan jawabanya bahwa tabung tersebut gambar dengan cara lingkaran pada alas dan tutup tabung dibagi 2 sehingga ada 4 lingkaran yang berbentuk setengah. Dan selanjutnya ada 2 persegi panjang yang terbentuk dari satu persegi panjang yang utuh. Jika masing-masing bangun datar yang digambarkan oleh siswa ini dijumlahkan, maka didaptkan adalah $1 / 2 \pi r^{2}+1 / 2 \pi r^{2}+1 / 2 \pi r^{2}+1 / 2 \pi r^{2}+1 / 22 \pi r t+1 / 22 \pi r t=4 / 2 \pi r^{2}+2 / 22 \pi r t=$ $2 \pi r^{2}+2 \pi r t=2 \pi r(r+t)$

. Lebih lanjut berikut ini uraian jawaban S3.

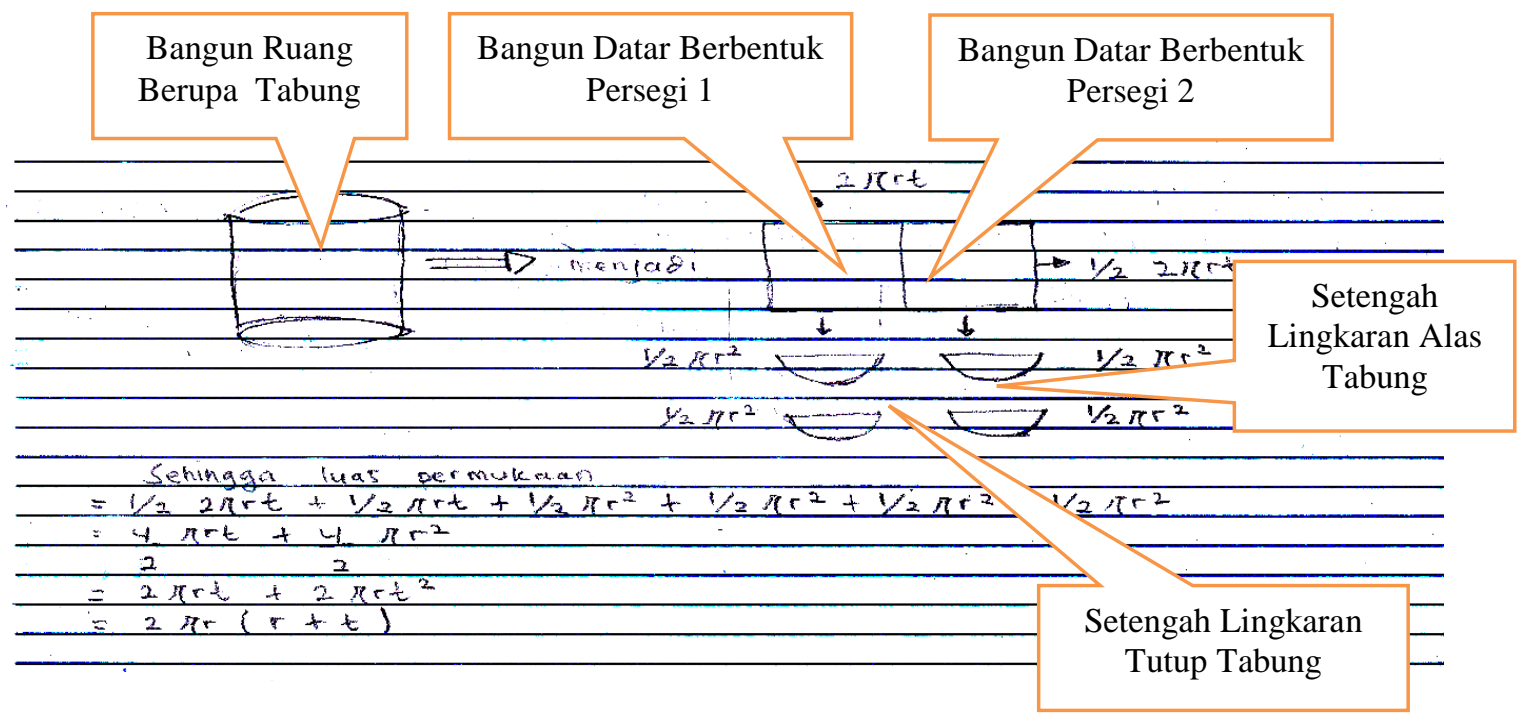

\section{Gambar 7. Jawaban soal pembuktian oleh S3.}


Selanjutnya jawaban siswa dari soal perhitungan luas permukaan tabung didapatkan bahwa mereka hanya menjawab seperti soal-soal perhitungan biasa. Tidak ada siswa yang memikirkan bahwa jika dari permukaan tabung tersebut dipotong permukaannya (tegak, atap, dan alasnya) ada pengurangan ukuran jari-jari atau tinggi tabung tersebut. Hal ini siswa masih memikirkan bahwa soal-soal yang dikerjakan oleh meraka masih tingkatanya sangat abstrak. Jawaban siswa adalah berikut ini.

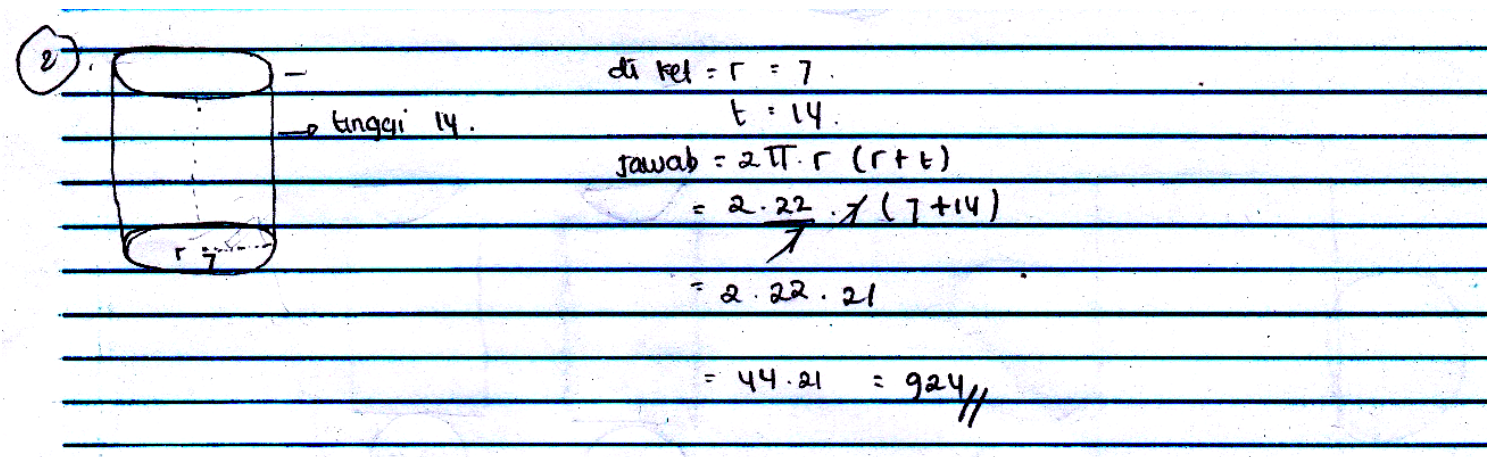

Gambar 8. Jawaban soal perhitungan oleh S1.

Dari uraian-uraian tersebut dapat dibuatkan struktur representasi ekternal siswa dalam kegiatan transisi pengetahuan dari bangun ruang ke bangun datar dalam membuktikan soal tersebut. Berikut ini langkah-langkah pemahaman mereka dalam transisi pengetahuan dari bangun ruang ke bangun datar untuk membuktikan luas permukaan tabung.

1. Siswa memahami masalah dengan mempertimbangkan tujuan dari pertanyaan

2. Siswa fokus pada pembuktian bahwa luas permukaan tabung adalah $2 \pi r(r+t)$

3. Siswa menyusun rencana

a. Luas persegi panjang yang ada pada permukaan tabung tersebut

b. Luas lingkaran yang ada pada permukaan tabung tersebut

c. Luas trapesium

d. Luas setengah lingkaran

e. luas 2 persegi panjang terpecah dari persegi panjang yang membentuk tabung

4. Siswa melaksanakan pembuktian

a. Luas selimut tabung yang berbentuk persegi panjang atau jajar genjang dengan panjang $2 \pi r$ dan lebar $t$

b. Luas lingkaran yang ada pada alas dan tutup tabung berturut-turut adalah $\pi r^{2}$ dan $\pi r^{2}$. 
Dari langkah-langkah pengejaan tersebut dapat digambarkan strukturnya sebagai berikut.

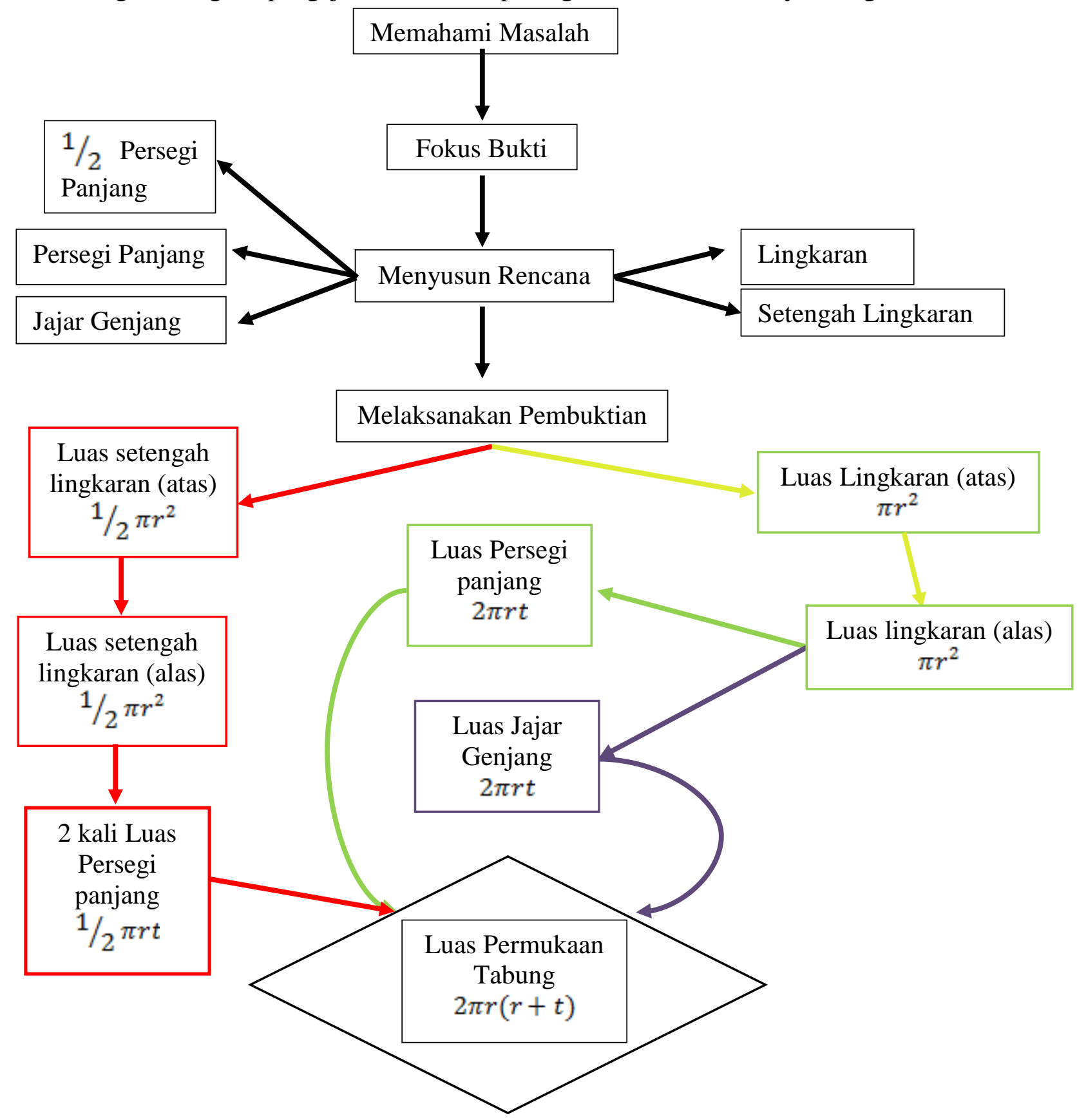

Gambar 8. Struktur Representasi Transisi Bangun Rung dalam pembuktian Luas Permukaan Tabung 


\section{SIMPULAN}

Hasil pekerjaan siswa dalam membuktikan luas permukaan tabung dengan cara merepresentasikan beberapa bentuk bangun datar. Bangun datar yang digambar adalah lingkaran penuh, setengah lingkaran, persegi panjang, jajar genjang, dan ada dua persegi panjang didapatkan pembagian dari satu persegi panjang yang membentuk tabung. Cara menjawab seperti ini merupakan representasi ekternal siswa yang berupa gambar dari bangun ruang menjadi bangun datar. Berbagai variasi cara mengambar untuk membuktikan luas permukaan tabung bisa dibentuk suatu struktur representasi ekternal siswa dari trasisi bangun ruang. Gambar strutur representasi eksternal siswa tersebut dapat dilihat pada gambar 8 .

\section{DAFTAR RUJUKAN}

Cox, R. 1999. Representation construction, externalised cognition and individual differences. Learning andInstruction, 9, 343-363.

Cuoco, A. A., \& Curcio, F. R. (Eds.). 2001. The roles of representation in school mathematics. National Council of Teachers of.

Irene T, Miura. 2001. The Roles of Representation in School Mathematics: The Influence of Language on Mathematical Representation. NCTM.

Hiebert, J., \& Carpenter, T. P. 1992. Learning and teaching with understanding.

Goldin, G., \& Shteingold, N. 2001. Systems of representations and the development of mathematical concepts. The roles of representation in school mathematics, 2001, 1-23.

Goldin, G. A. 2002. Representation in Mathematical Learning and Problem Solving. In L.D English (Ed) International Research in Mathematical Education IRME, 197-218. New Jersey: Lawrence Erlbaum Associates.

Mayer, RE 2001. Multimedia learning. Cambridge, UK: Cambridge University Press. NCTM 2000. Principles and Standards for School Mathematics, Reston, Virginia. Patricia. C. Alcaro, dkk. 2000. Fractions Attack! Children Thinking and Talking Mathematically. Teaching Children Mathematics Vol 6 No 9 Mei 2000. Hal: 562-567

Wetzels, S., Kester, L., \& Van Merriënboer, J. 2010. Use of external representations in science: Prompting and reinforcing prior knowledge activation. 